\title{
Impact of Rewards Management System on Employees' Satisfaction in Case of DebreBirhan University Administrative Staffs
}

\author{
Gebayaw Adugna Admassie \\ Department of Management, College of Business and Economics DebireBirhan University, DebireBirhan, Ethiopia
}

Email address:

geb.adu@gmail.com

\section{To cite this article:}

Gebayaw Adugna Admassie. Impact of Rewards Management System on Employees' Satisfaction in Case of DebreBirhan University Administrative Staffs. Journal of Investment and Management. Vol. 8, No. 1, 2019, pp. 16-24. doi: 10.11648/j.jim.20190801.13

Received: December 16, 2018; Accepted: February 12, 2019; Published: February 20, 2019

\begin{abstract}
Reward management is concerned with the processes of developing, implementing, operating and evaluating reward policies and practices that recognize and value people according to the efforts and contributions they make towards achieving organizational, departmental and team goals. Employee satisfaction is the degree to which an employee has positive emotions towards the work and organization. The objective of the study is to determine the impact of reward management system on employees' satisfaction in DebireBirhan University administrative staffs in Ethiopia. The sample size of the study contained 280 administrative staffs in the different departments" of University. Data was collected using structured questionnaire technique. The data obtained was processed using the statistical package for social science (SPSS) and was analyzed using both descriptive and inferential statistics. The result discussion indicate that there was a moderate significant positive relationship between transparency of reward system and Employees satisfaction $(r=0.582, p<0.00)$, Fair distribution reward system and Employees satisfaction $(\mathrm{r}=0.562, \mathrm{p}<0.00)$. Low significant positive relationship between Equity reward system and employees satisfaction $(\mathrm{r}=0.336, \mathrm{p}<0.00)$; Consistency and continuity of reward system and Employees satisfaction $(\mathrm{r}=0.388, \mathrm{p}<0.00)$. The study found that reward management system collectively have significant effect on employees satisfaction. The study recommends that the university reward management system should be transparency, equity, fair distribution and consistency among administrative staffs in the university. The university should be developing channels of communication for making transparency and clarity of reward management system to administrative staffs.
\end{abstract}

Keywords: Equitable Reward, Transparency, Consistency and Continuity Reward System, Employees, Satisfaction and Administrative Staffs'

\section{Introduction}

According to Manus and Graham, total reward includes all types of rewards - indirect as well as direct, and intrinsic as well as extrinsic' Total reward strategies are vertically integrated with business strategies, but they are also horizontally integrated with other HR strategies to achieve internal consistency [23].

As Armstrong and Brown emphasize: 'Resourcing and reward strategies which are heavily focused on either recruiting young "dynamic" staff and getting rid of "old" employees at a fixed retirement date or before; or the opportunistic poaching of staff with the requisite skills and experience from competitors [4].
According to Khawaja Jehanzeb et al, the degree of rewards, motivation and job satisfaction of employees has a strong relationship in the banking sector of Saudi Arabia [18]. Decision on the implementation of effective reward systems aimed at increasing employee satisfaction [27].

Contingent pay is a pay for individuals that is related to performance, competence, contribution and service provided by employees which distributes according to equity theories [27]. Khan et. al, conducted a study on impact of rewards on employee motivation in Commercial Banks [17]. The study showed a positive significant relationship between rewards and employee motivation among the employees ${ }^{\text {ee }}$ of commercial banks in Pakistan. According to the study findings, motivated employees are more energetic and 
productive on their work.

\subsection{Statement of the Problem}

Armstrong argues that when rewards are well managed, desired commitment are achieved efficiently and effectively since the employees get a sense of mutual gain [5].

According to Mahlet, unpuplished study, the Tikur ambessa and Alert hospital reward system (payment, promotion, reorganization, and benefits), work content and condition which positive and significance relationship with employee work motivation/ satisfaction [21]. Michael and Helen described total reward accountable for all the ways in which people can be rewarded and obtain satisfaction through their work [24]. Employee rewards may be looked at as total reward which refers to the compensation which an employee receives from an organization for rendering his or her services [15]. It includes all the financial and nonfinancial benefits that are given by an organization to its employees. Singh states that rewards management has an element of behavioral objective that aims to fulfill a need and motivate employees in order to achieve the goals of an organization [30].

The connections between rewards, motivation and job satisfaction of employees are strategically significant to the success of public and private organizations [29]. According to Molahosseini et al, behavior of employees in all organizational levels is affected by the behavior of managers which is derived from their power to use resources [26]. Therefore, managers can use rewards so as to motivate the behavior of employees and thereby attain the required organizational results. Armstrong states, reward management is based on the principles about what the organization wants to achieve [5]. Therefore, an organization must align its reward practices with both the employee needs and the goals of the business in order to achieve its objectives.

DebreBirhan University implementing deferent reforms at different time for the purpose of maximizes employees and organization performance. According to annual reports of DebreBirhan University different types reforms implemented, for instance, Business process reengineering (BPR) [8] and Balanced Scorecard (BSC) [9]. All of reforms focused towards how to exploit human capitals to maximize the organizational performance, but not incorporated reward management system in right manner. All the doctrine of reforms implemented by university focused on flow tasks and improved employees' and organization performance to maximize customer satisfaction. But reforms were ignoring employees' satisfaction on the reward management system in the university.

Therefore, it is evident that there is a knowledge gap to be filled. As a result, the purpose of this study is to fill this gap by determining the impact of reward management system on administrative staffs' satisfaction in DebireBirhan University.

\subsection{Hypothesis}

The following hypothesis tested in this study
H1: There is positive linear relationship between transparency reward systems of University and employees' satisfaction.

$\mathrm{H} 2$ : There is positive linear relationship between equitability reward system of University and employees' satisfaction.

H3: There is positive linear association between fair distribution of reward system and employees' satisfaction.

H4: There is positive linear relationship between consistency of reward system and employees' satisfaction.

H5: transparency reward system has significantly and positively affects employees' satisfaction.

H6: Equitability reward system has significantly and positively effects on employees' satisfaction.

H7: fair distribution of reward system has significantly and positively affects employees' satisfaction.

H8: consistency and continuity reward system has significantly and positively affects employees' satisfaction.

The specific objectives of the study are:

1. To determine equitable reward system of the University and its impact on employees' satisfaction of administrative staff.

2. To determine the fair distribution of reward system of University and its impact on employees' satisfaction of administrative staff.

3. To determine the consistency and continuity reward system of the University and its impact on employees' satisfaction of administrative staff.

4. To assess the transparency level of reward system of the University and its impact on employees' satisfaction of administrative staff.

\subsection{Weaknesses and Strength of Study}

This study is not free from weaknesses. As result, the study failed to incorporate competence of employees, leadership styles and working environment as a variable to be investigated under consideration. The study focuses only the impact of reward management system on employees' satisfaction and also the study confined merely one university in the country, Ethiopia.

Apart from the weakness, the study used pilot test for cross checking validity and reliability of data through scientific procedure. Besides, the study incorporates reward management system variable highly influences employees satisfaction than other variables.

\section{Literature Review}

\subsection{Total Reward Management System}

Total reward strategy is a holistic approach aligning with business strategy and people strategy; it encompasses everything employees value in their employment relationship like compensation, benefits, development and the work environment [16]. Total reward combines the impact of the two major categories of reward: 1) transactional rewards tangible rewards arising from transactions between the 
employer and employees concerning pay and benefits; and 2) relational rewards - intangible rewards concerned with learning and development and the work experience.

Worldat Work stated that, total rewards are 'all of the employer's available tools that may be used to attract, retain, motivate and satisfy employees' [35]. On other hand, Thompson, p suggests that: 'total reward typically encompass not only traditional, quantifiable elements like salary, variable pay and benefits, but also more intangible non-cash elements such as scope to achieve and exercise responsibility, career opportunities, learning and development, the intrinsic motivation provided by the work itself and the quality of working life provided by the organization[32].'

Datta argues that many organizations consider employees as their main factor in creating organizational value and competitive advantage. As a result, it is important to maintain employees, create motivation and increase job productivity through diverse strategies like rewards [11]. Therefore, it is necessary for companies to design reward systems based on employees' skills and capabilities as well as in accordance with the organizational goals so as to improve performance and motivation.

The total reward is the sum of total remuneration and nonfinancial rewards whereas the total remuneration is the sum of base pay, contingent pay and the value of employee benefits [24]. Some scholars divided reward in to financial and non- financial reward. The financial rewards include rewards strategies such as merit-pay, market-based pay, profit-related pay, while non-financial rewards focus on the needs of people for recognition, achievement, responsibility and personal growth [34].

The reward management system should be designed to support the achievement of the organization's strategies; it should be based on a philosophy of reward which matches the culture of the organization. As Armstrong and Murlis emphasis reward helps the process promote motivating, commitment and engagement of employees. It is working with people, investing on workers and provided any return for employees' contribution [2].

\subsubsection{Reward Management and Performance Management}

According to Molahosseini et al, reward management systems should be designed in a way that ensures maximum benefits for an organization. This requires rewards to be designed in a way that leads to effective organizational performance [26].

The Michael \& Helen described that, reward management is development, implementation, maintenance, communication and evaluation of reward employees. It works on reward to allocate fairly the salary and benefits as per the employees contribution [2]. Michael and Helen illustrate, the effective performance management is a powerful means of providing total reward [24]. According to Dalvi and Ebrahimi, a well-designed reward system creates a sense of belonging among employees in an organization. It enhances employee growth and development, and increases employee self-esteem and this leads to healthier organizations [10].

According to Michael and Helen, there are two basic reward philosophy; they are entitlement oriented philosophy and performance-oriented philosophy [24]. Entitlement Orientation philosophy is the traditional organization increases the salary and other benefits based on the years of service of employees. Performance Orientation philosophy is followed, no one is guaranteed compensation just for adding another year to organizational service. Instead, pay and incentives are based on performance differences among employees.

\subsubsection{Reward System}

Stephen and Geoff determined reward system in terms of 'employee reward' and 'reward management'. The employee reward is re-categorized into extrinsic, tangible or transactional reward for undertaking work in employment which concrete on response or award for the employees' performance [31].

Extrinsic reward help to fulfill the human being related to biological and physical needs like food, shelter, cloth and others award from work what employees accomplished. The other employee reward is intrinsic reward which derived from work and employment which encourages employees to motivation and satisfaction on their responsibility and position work. Intrinsic reward more psychological satisfaction related self-esteem, self-actualization and recognition of employees that gained from work itself rather than money and others remuneration. The reward system is approaches to achieving the aims of reward management; it consists of reward strategies, reward policies, practices, processes and procedures that will further help the achievement of its company objectives. [24].

\subsubsection{Reward Strategy}

Reward strategy clarifies what the organization wants to do in the longer term to develop and implement reward policies, practices and processes that will further the achievement of its business [2]. It is a declaration of intent, which establishes priorities for developing and acting on reward plan that, can be aligned to business and human resource strategies and to the needs of people in the organization. According to Armstrong, reward management is concerned with the processes of developing, implementing, operating and evaluating reward policies and practices that recognize and value people according to the efforts and contributions they make towards achieving organizational, departmental and team goals [5]. Therefore, reward management should serves as a means of motivating employees. In other words as Armstrong and Murlis defined, the reward strategy is 'the process of looking ahead at what an organization needs to do about its reward policies and practices in the middle or relatively distant future [3].' Reward strategy is 'the direction in which reward management innovations and developments to support the business strategy, how they should be integrated, the priority that should be given to initiatives and the pace at which they should be implemented'. 


\subsubsection{Reward Policy and Practices}

Reward policy established based on job evaluation which is the formal processes by which the relative worth of various jobs in organization is determined for pay purposes (Glueck, 1978). Furthermore, reward policies should take into account organizational goals, values [3].

Michael Armstrong mentioned that, the reward management practices operate in accordance with the principles of distributive and natural justice function like aligned to the business strategy, competitiveness, compliance, flexible and fit the context and culture of the organization[24]. The Michael \& Helen illustrated, the reward processes is powerful media for conveying messages to employees about the organization's values and the contribution they are expected to make in upho [24].

lding those values and achieving the organization's goals

\subsubsection{Communication and Transparency of Reward System}

Michael and Helen stated the reward transparency the right things to convey the right message about what is important in terms of expected behaviors and outcomes [24]. According to Boxall and Purcell, Employee voice is the term increasingly used to cover a whole variety of processes and structures which enable and sometimes empower employees directly and indirectly to contribute to the decision making in the firm [6]. Concept of the 'democratic enterprise' focuses on the quality of openness during communication between the individual and his or her boss' as well as the involvement the individual feels in the everyday working of the organization founds that reward practice satisfied full transparency of awards, communication availability of reward, the criteria to be satisfied and the identification of the award recipients $[13$, 14].

\subsection{Employees Satisfaction Concepts}

Armstrong observes that employees are satisfied with their jobs in organizations that provide competitive rewards and this makes them to want to stay in the same organizations thereby leading to high levels of employee retention [5].

Collins defined employee satisfaction as the degree to which an employee has positive emotions towards the work and organization [7]. Employee's satisfaction is vital for their well-being and organizational effectiveness. Job satisfaction is further premised to encourage employees to be committed and stead fast to the organizations where they work and belong [22].

The Valuably of Reward System in Employees Satisfaction.

According to Thorpe and Homan, one of the most fundamental debates in the field of rewards management, concerns the extent to which employees are motivated and satisfied by money [33]. At that point there are extensive views about whether or not money is a motivator and can influence the levels of employees' satisfaction. Andualem findings imply no correlation between reward packages and employee satisfaction [1].

Money is important to people because it is instrumental in satisfying a number of their most pressing needs. It is significant not only because of what they can buy with it but also as a highly tangible method of recognizing their worth, thus improving their self-esteem and gaining the esteem of others [24].

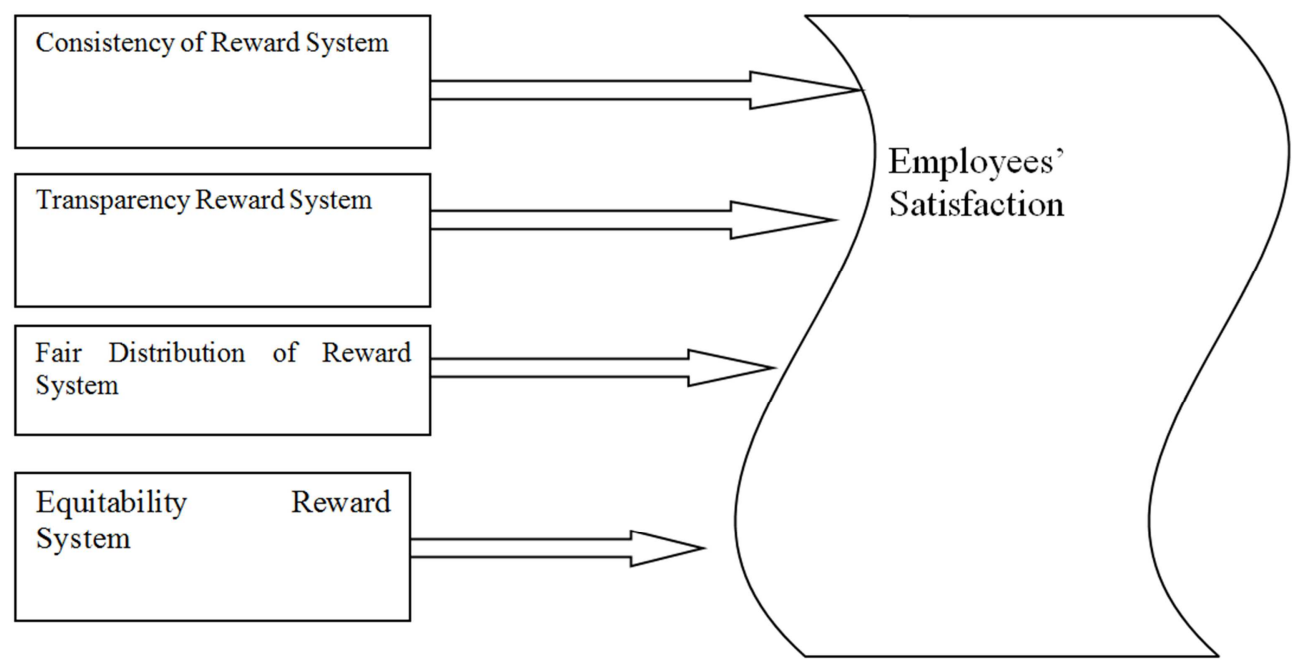

Figure 1. Conceptual Framework and Model: Reward System on Employee Satisfaction.

\section{Methodology}

A research design can be regarded as an arrangement of conditions for collection and analysis of data in a manner that aims to combine relevance with the research purpose. It is the conceptual structure with in which research is conducted. It constitutes the blue print for collection, measurement and analysis of data [19]. And descriptive survey research design and quantitative research approach were employed in this study.

To test hypotheses correlation and regression analysis; a quantitative correlation and regression type of analysis are one part of a descriptive type of research design. According to Kothari correlation study tries to study a problem so as to explain the relationship between variables [19]. The study 
was cross sectional survey study. Cross sectional survey is a type of observational study that involves the analysis of data collected from a population, or a representative subset. It involved collection of primary data at specific point in time. This is opposed to longitudinal study which involves collection of primary data over a long period of time.

The target population for the study encompassed all administrative staffs' from the DebireBirhan University within the Ethiopian County. The sample size of employees that were studied was determined by the use of the formula [19]. The study used simple random sampling to select respondents from each department. From the 1025 administration staffs' 280 respondents selected with simple random sampling from list of administrative department in the University.

The formula used to calculate sample size is shown below.

$$
\begin{gathered}
\mathrm{n}=\mathrm{Z}^{2} * \mathrm{P} * \mathrm{Q} * \mathrm{~N} \\
\mathrm{e}^{2}(\mathrm{~N}-1)+\mathrm{Z}^{2 *} \mathrm{P} * \mathrm{Q}
\end{gathered}
$$

Where,

$p=$ sample proportion, $q=1-p$;

$\mathrm{Z}=$ normal reduced variable at 0.05 level of significance $\mathrm{Z}$

is 1.96

$\mathrm{N}=$ size of population which is the number of Employees

$n=$ size of sample.

Source; Kothari. C 2004

\begin{tabular}{|c|c|c|c|}
\hline No. & Department & Population & Sample selected \\
\hline 1 & Purchasing and procurement department & 89 & 24 \\
\hline 2 & Human resource management department & 19 & 5 \\
\hline 3 & Finance department & 23 & 7 \\
\hline 4 & Compound service department & 64 & 18 \\
\hline 5 & Student service department & 180 & 49 \\
\hline 6 & Library service department & 203 & 56 \\
\hline 7 & Distance and continuing education department & 29 & 8 \\
\hline 8 & Research and publication department & 47 & 13 \\
\hline 9 & Printing and publication department & 23 & 6 \\
\hline 10 & Colleges officers and secretary administrative & 102 & 27 \\
\hline 11 & President office & 74 & 20 \\
\hline 12 & Academic vice president office & 12 & 3 \\
\hline \multirow[t]{2}{*}{13} & Lab assistance & 160 & 44 \\
\hline & Total & 1025 & 280 \\
\hline
\end{tabular}

Table 1. Proportional, distribute the administrative Staffs per department.

Source: Own survey, 2018.

Validation and Reliability

Validity measures the ability of the research instruments to measure what it is intended. To ensure face and content validity was achieved, thorough literature review was done in order to develop the questionnaire items so as to ensure that it tapped all the study variables. For further refine the accuracy of the instrument, the questionnaires were evaluated and edited by research experts and human resource management professionals.

According to Mugenda reliability of an instrument is the degree of consistency with which it measures a variable. Reliability measure the degree of repeated the same result obtained from data collecting questionnaire in different time [7]. In this study, to ensure reliability of the instrument, the questionnaires were pilot tested amongst the administrative staffs of DebireBirhan University to ensure that the questionnaire items were understandable and free of ambiguity. Reliability coefficient (alpha value) of more than
0.7 is assumed to be reliable. Reliability assessments using Cronbach alpha coefficient has exceeded ' 0.798 ' for all variables in this study. The hypotheses test were accepted at $99 \%$ and rejected at $95 \%$ confidence level, it was ensured the internal reliability.

\section{Results and Discussion}

The Correlation Coefficient between Employees' Satisfaction and Each Four Feature of Reward System

The correlation coefficients represent the relationship between two or more variable. The correlation coefficient (R) indicates degree of relationship between two variables; if $R=$ -1 , the two variables are perfectly negatively correlated; if $\mathrm{R}=$ $(-1,-0.3)$, negatively correlated; if $\mathrm{R}=(-0.3,0.3)$, no correlation; if $\mathrm{R}=(1,0.3)$, positively correlated and if $\mathrm{R}=1$, perfectly positively correlated.

Table 2. The Correlation Coefficient between Employees'Satisfaction and Each Four Feature of Reward System.

\begin{tabular}{lllll}
\hline & & $\begin{array}{l}\text { Transparency of } \\
\text { reward system }\end{array}$ & $\begin{array}{l}\text { Equity reward } \\
\text { system }\end{array}$ & $\begin{array}{l}\text { Fair distribution } \\
\text { reward system } \\
\text { continuity of reward } \\
\text { system }\end{array}$ \\
\hline Employees & Pearson Correlation & $.582^{* *}$ & $.336^{* *}$ & $.562^{* *}$ \\
satisfaction & Sig. (2-tailed) & .000 & .000 & .000 \\
\hline
\end{tabular}

Source: Own survey, 2018. 
Ho: there is positive linear relationship between transparency of reward systems and employees' satisfaction.

$\mathrm{H} 1$ : different from $\mathrm{Ho}$, that is $\mathrm{H} 1 \neq \mathrm{Ho}$.

From the above output of SPSS Table 2there is Positive relationship coefficient between transparency of reward system and employees' satisfaction $\left(\mathrm{r}=0.582^{* *}\right)$ and a statistically significant $(\mathrm{p}<0.01)$. linear relationship between these two variables such that the high transparency rewards system reflects more employees' satisfaction. So, the null hypothesis is accepted.

Hypothesis .2:

Ho: there is positive linear relationship equitability reward system and employees' satisfaction.

$\mathrm{H} 1$ : different from $\mathrm{Ho}$, that is $\mathrm{H} 1 \neq \mathrm{Ho}$.

There is a positive relationship coefficient between equitability reward system of the University and employees' satisfaction $(\mathrm{r}=0.336)$ and statistically significant $(\mathrm{p}<0.01)$. Linear relationship between these two variables such that as the equity reward system of the University improved the employees' satisfaction. Therefore, the null hypothesis is accepted.
Hypothesis 3:

Ho: There is positive linear relationship between fair distribution of reward system and employees' satisfaction.

$\mathrm{H} 1$ : Different from Ho, that is $\mathrm{H} 1 \neq \mathrm{Ho}$.

There is a Positive correlation coefficient among fair distribution reward system and employees' satisfaction ( $\mathrm{r}=$ $0.562)$ and a statistically significant $(p<0.01)$. Linear relationship between these two variables such that as the fair distribution reward system of the University improved the employees' satisfaction. As a result, the null hypothesis is accepted.

Hypothesis.4:

Ho: There is positive linear relationship between consistency of reward system and Employees' satisfaction.

$\mathrm{H} 1$ : Different from Ho, that is $\mathrm{H} 1 \neq$ Ho.

There is positive correlation coefficient between consistency $\&$ continuity reward system and employees' satisfaction ( $\mathrm{r}=$ $0.388)$ and a statistically significant $(p<0.01)$. linear relationships between these two variables such that as the consistency reward system increase the employees' satisfaction. Hence, the null hypothesis is accepted.

Table 3. Coefficient of Determination of Multiple Regressions Analyses.

\begin{tabular}{lllll}
\hline Model Summary & & & & \\
\hline Model & R & R Square & Adjusted R Square & Std. Error of the Estimate \\
\hline 1 & $.678^{\mathrm{a}}$ & .459 & .451 & .38505 \\
\hline
\end{tabular}

a. Predictors: (Constant), Consistency and continuity of reward system, Equity reward system, Fair distribution reward system, Transparency of reward system

The above table 3 shows the amount of variation in the dependent variable - employee satisfaction that is accounted for by the optimal linear combination of the entire set of independent variables Transparency of Reward System, Equity Reward, Fair Distribution of Reward System, Consistency \& continuity of Reward System are expressed by R square which is 0.459 , and adjusted $\mathrm{R}$ square is 0.451 . This indicates the regression, expressed through the adjusted $\mathrm{R}$ square is statistically significant where the percentage of variation in employee satisfaction explained by the four variables accounts for $45.1 \%$, and other unexplored variables may explain the variation in employee satisfaction which accounts for $54.9 \%$.

In order to determine the extent to which the explanatory variables explain the variance in the explained variable, multiple regression analysis was performed. Regression is a measure of association between two quantitative variables or two sets of variables.

Multicollinearity Test:in multiple regression analysis, multicollinearity refers to the correlation among the independent variables. The Variance Inflation Factor (VIF) and Tolerance of Independent variables are utilized to confirm that whether there was or no multicollinarity in the model. In table. 3 values of VIF and tolerance of all independent variables are given. As the values of VIF for each independent variable is less than cut point 5 (in this case the maximum is 1.926) and tolerance value of each independent variable is greater than cut point 0.2 (the minimum in this case is 0.519 ), so this confirm that there is no evidence of occurrence of multi -colinarity in the regression estimates.

Level of employee Satisfaction $=\beta 0+\beta 1$ (Transparency of Reward System) + $\beta 2$ (Equity Reward) $+\beta 3$ (Fair Distribution of Reward System) $+\beta 4$ (Consistency \& continuity of Reward System).

$$
\mathrm{ESB}=\beta 0+\beta 1 \mathrm{TR}+\beta 2 \mathrm{ER}+\beta 3 \mathrm{FDR}+\beta 4 \mathrm{CR}
$$

Where: $\beta 0, \beta 1, \beta 2, \beta 3$ and $\beta 4$ are coefficients of a regression model; ES is dependant variable, and TRB, ERB, FRB \& CRB are independent variables.

Table 4. Results of Regression Analyses: Predictor Variables on overall Employee Satisfaction.

\begin{tabular}{|c|c|c|c|c|c|c|c|}
\hline \multirow{2}{*}{ Model } & \multicolumn{2}{|c|}{ Unstandardized Coefficients } & \multirow{2}{*}{$\begin{array}{l}\text { Standardized Coefficients } \\
\text { Beta }\end{array}$} & \multirow{2}{*}{$\mathbf{T}$} & \multirow{2}{*}{ Sig. } & \multicolumn{2}{|c|}{ Collinearity Statistics } \\
\hline & B & Std. Error & & & & Tolerance & VIF \\
\hline (Constant) & .700 & .200 & & 3.494 & .001 & & \\
\hline Transparency of reward system & .226 & .064 & .228 & 3.539 & .000 & .519 & 1.926 \\
\hline Equity reward system & .164 & .059 & .152 & 2.786 & .006 & .729 & 1.373 \\
\hline Fair distribution reward system & .307 & .060 & .319 & 5.080 & .000 & .548 & 1.824 \\
\hline $\begin{array}{l}\text { Consistency and continuity of reward } \\
\text { system }\end{array}$ & .133 & .043 & .162 & 3.088 & .002 & .784 & 1.275 \\
\hline
\end{tabular}


$\mathrm{ESB}=0.700+0.226 \mathrm{TRB}+0.164 \mathrm{ERB}+0.307 \mathrm{FRB}+$ $0.133 \mathrm{CRB}+$ error

Transparency, equity, fair distribution and consistency of reward system have positive effect on the employees' satisfaction.

The estimated coefficient transparency of reward system is 0.226 . Other variables constant, transparency of reward system of the University influence within $22.6 \%$ on employees' satisfaction.

The estimated coefficient of equitability reward system of the University is 0.164 . Other variables constant, equitability reward system of the University influence within $16.4 \%$ on employees' satisfaction.

The estimated coefficient of fair distribution reward system is 0.307 . Other variables constant, fair distribution reward system of the University influence within $30.7 \%$ on employees' satisfaction.

The estimated coefficient of consistency and continuity of reward system is 0.133 . Other variables constant, consistency and continuity reward system of the University influence within $13.3 \%$ on employees' satisfaction.

Tests of Regression coefficients

To test whether each of the coefficients is significant or not, the hypotheses are as follows:

If $\left|t_{c a l}\right|>p$-value, accept the null hypothesis and reject the alternative hypothesis.

The constant term (intercept) is significant. Since Sig. > 0.05 , so it is important variable!

H5: Transparency Reward system has significantly and positively affects employees' satisfaction.

Ho: $\beta 1 \neq 0$,

$\mathrm{H} 1: \beta 1=0$

Decision: the test statistic of transparency of reward system $\left|\mathrm{t}_{\text {cal }}\right|=3.539>\mathrm{p}$-value $=0.00$. Hence, accepts the null hypothesis and reject alternative hypotheses. This implies that transparency of reward system has significantly effects on employees' satisfaction of DebireBirhan University at the $1 \%$ level of significance.

H6: Equitability reward system of the University has significantly and positively affects employees' satisfaction.

Ho: $\beta 1 \neq 0$,

$\mathrm{H} 1: \beta 1=0$

Decision: the test statistic of equitability reward system of the University $\left|\mathrm{t}_{\text {cal }}\right|=2.786>\mathrm{p}$-value $=0.00$. So, accept the null hypothesis and reject alternative hypotheses. This implies that equitability reward system of the University has significantly affects on employees' satisfaction of DebireBirhan University at the 1\% level of significance.

H7: Reward system fair distributing of reward system has significantly and positively affects employees' satisfaction.

Ho: $\beta 1 \neq 0$,

$\mathrm{H} 1: \beta 1=0$

Decision: the test statistic of fair distributing of reward system $\left|\mathrm{t}_{\text {cal }}\right|=5.08>\mathrm{p}$-value $=0.00$. Therefore, accept the null hypothesis and reject alternative hypotheses. This implies that fair distributing of reward system has significantly effects on employees' satisfaction of DebireBirhan University at the $1 \%$ level of significance

H8: Consistent \& Continuity Reward System will have significantly and positively affects employees' satisfaction.

Ho: $\beta 1 \neq 0$,

$\mathrm{H} 1: \beta 1=0$

The test statistic of consistent \& continuity reward system $\left|\mathrm{t}_{\text {cal }}\right|=3.088>\mathrm{p}$-value $=0.00$. As a result, accept the null hypothesis and reject alternative hypotheses. This implies that consistent \&continuity reward system has significantly effects on employees' satisfaction of DebireBirhan University at the $1 \%$ level of significance.

\section{Conclusion}

This study investigated the effect of rewards management system on employees' satisfaction. The study found that transparency, equity, fair distribution and consistency of reward system have positive effect on the employees' satisfaction. Inference statistics of the research findings show that DebireBirhan University has limitation on transparency, equity, fair distribution and consistency of reward system to administrative staffs. Lack of transparency, equity, fair distribution and consistency of reward system are source of dissatisfaction and grievance employees. Dissatisfaction employees are not productive. So, total reward management system affects organizational performance. The study was cross-sectional which means that the data was collected at one point in time. This means that the study was unable to capture the long-term effect of rewards management systems on employees' satisfaction.

The following recommendations are suggested: The University reward management system should be transparency, equity, fair distribution and consistency among administrative staffs in the university. The top management of the University should be used research finding on area of reward management system and suggestion of human resource management specialists as input to develop of reward packages to administrative staffs in University. The University should be developing channels of communication for making transparency and clarity of reward management system to administrative staffs. Top management of University formulation and implementation of reward management system should be done in order to enhance employees' satisfaction align with the performance of employees.

University should be examine employees' satisfaction level on reward management system, and provide appropriate reward benefit package to employees accordingly their contribution to university performance. This study recommends that top University management must fully appreciate whether or not total rewards management practice influence employee satisfaction. The study findings can be advantageous to human resource specialists who are required to recognize the role of total rewards management on employees' satisfaction. Furthermore, the decision making 
organs of University ought to consider implementing the findings of this study because it may assist them in determining the appropriateness of various elements of total rewards management system to enhancing employees' satisfaction and organizational performance. Finally, the results of the study add knowledge to the existing literature and therefore act as a vehicle for future studies aimed at investigating issues related to total reward management system and employees satisfaction.

\section{References}

[1] Andualem T. (2013): Reward and employee satisfaction: A case study of admass University College. Master's Degree Thesis, Addis Ababa University School of Commerce.

[2] Armstrong M. \& Murlis H. 1998. Rewards Management: A Handbook of Remuneration Strategy and Practice. $4^{\text {th }}$ ed. United Kingdom and the United States, Kogan Page.

[3] Armstrong M. \& Murlis H. 2007. Rewards Management: A Handbook of Remuneration Strategy and Practice. $4^{\text {th }}$ ed. Kogan Page.

[4] Armstrong, M and Brown, D. 2006. Strategic Reward. Kogan Page, London.

[5] Armstrong, M. 2012. Armstrong's Handbook of Human Resource Management Practice. New York, NY, Kogan Page Publishers.

[6] Boxall P. and Purcell J. 2003. Strategic Human Resource Management, London, Routledge.

[7] Collins C. 2007. The interactive effects of recruitment practices and product awareness on job seekers' employer knowledge and application behaviors. Journal of Applied Psychology, 92: 180-19.

[8] DebreBirhan University Annual report, 2010. Implementation of Business Process Reengineering.

[9] DebreBirhan University Annual report, 2012. Implementation Balanced score card reform.

[10] Dalvi, M., \& Ebrahimi, H. 2013. Investigating the Effects of Reward on the Cooperation in the Sale and Marketing Department from Managers' Perspective (Isfahan Food industries Case Study). International Journal of Academic Research in Business and Social sciences, 3 (1): 144-153.

[11] Datta, P. 2012. An Applied Organizational Rewards Distribution System. Management Decision, 50 (3): 479-501.

[12] Glueck, W. 1978. Personnel Diagnostic Approach. Texas Business Publications, Inc.

[13] Gratton, L. 2004. The Democratic Enterprise: Liberating your business with freedom, flexibility and commitment. FT Prentice Hall, London.

[14] Ivana N, Lovorka G., \& Nevenka C. 2009. Corporate Culture and Innovation: Implications for Reward Systems. World Academy of Science, Engineering and Technology, pp. 397402.

[15] Jiang, Z., Xiao, Q., I, H., \& Xiao, L. 2009. Total Rewards Strategy: A Human Resources Management Strategy Going with the Trend of the Times. International Journal of Business and Management, 4 (11): 177-184.

[16] Kaplan, S. L. 2007. Business Strategy, People Strategy and Total Rewards. Benefits \& Compensation Digest, Vol. 44 (9).

[17] Khan, K, U, Syed Umar Farooq, Zilakat Khan. 2010. A Comparative Analysis of the Factors Determining Motivational Level of Employees Working in Commercial Banks in Kohat, Khyber Pukhtunkhwa. International Journal of Business and Management, Vol. 5 (12).

[18] Khawaja Jehanzeb et al. 2012. Impact of Rewards and Motivation on Job Satisfaction in Banking Sector of Saudi Arabia: International Journal of Business and Social Science Vol. 3 (21).

[19] Kothari, C 2004. Research Methodology: Methods and Techniques. New Delhi, New Age International Publishers.

[20] Kothari, C. 2008. Research Methodology: Methods and Techniques. New Delhi, New Age india International.

[21] Mahlet A. 2012: Reward and employee satisfaction: A comparative study Tigur ambessa and Alert hospital reward system. Master's Degree Thesis. Addis Ababa University School of Commerce.

[22] Malik M., Nawab S., Naeem B. and Danish R. 2010. Job Satisfaction and Organizational Commitment of University Teachers in Public Sector of Pakistan. International Journal of Business and Management, vol 5:17-26.

[23] Manus, TM and Graham, MD. 2003. Creating a Total Rewards Strategy. American Management Association, New York.

[24] Michael A. and Helen M. 2007. Reward Management: a Handbook of Remuneration Strategy and Practice. $5^{\text {th }}$ revised. ed. London, Kogan.

[25] Micheal A. and Helen M. 2004. Reward management: A handbook of remuneration strategy and practice. $4^{\text {th }}$ Ed. United kingdom and the United States, Kogan page.

[26] Mollahosseini, A., Kahnouji, K., Shamsiyeh, A., \& Kahnouji, A. 2014. An Assessment of the Relationship between Managers' Power Resources and Employees Commitment of Governmental Organizations in Rafsanjan South Eastern Iran. International Journal of Academic Research in Economics and Management Science, 3 (1): 244-256.

[27] Narsee, N. 2012. Comparing the Impact of Monetary and Non-Monetary Reward Programs towards Employee and Organizational Motivation. Master Thesis, Gordon Institute of Business Science.

[28] Navid Niki. 2012. Designing Distribution system of rewards and influence on Employees Satisfaction Case Study, Hamgamkhodro Asia factory: International Journal of Business and Social Science Vol. 3 (12).

[29] Schuler, R. S., and Jackson, S. E. 1996. Human Resource Management: Positioning for the $21^{\text {st }}$ Century. $6^{\text {th }}$ edition. New York, West Publishing Company.

[30] Singh, S. 2007. Compensation and Rewards Management. New Delhi, Excel Books.

[31] Stephen J. and Geoff W., 2011. Reward Management, $2^{\text {nd }}$ Edition. Published by the CIPD. 
[32] Thompson, P., 2002. Total Reward: Chartered Institute of Personnel and Development, London.

[33] Thorpe R. 2000. Reward Strategy, in Thorpe, R. and Homan G. (eds). Strategic Reward Systems. Financial Times Prentice Hall.

[34] White G. \& Drucker J. 2000. Reward Management: A critical text. Routledge: London and New York.

[35] Worldat Work, 2000. Total Rewards: from strategy to implementation, Scottsdale, AZ.
[36] Welman, J., Kruger, S. 2004. Research methodology for the business and administrative sciences. Pretoria. Oxford University.

[37] Marczyk, J. Dematteo, D. \&Festtinger, D. (2005). Essential of research design and methodology, John Wiley \& sons, Inc.

[38] Collis J. \& Hussey R. (2003): Business research; a practical guide for undergraduate and postgraduate. $2^{\text {nd }}$ edition. New York: Palgrave Macmillan. 